\title{
Poor Quality of Sleep Among HIV-Positive Persons in Ethiopia
}

This article was published in the following Dove Press journal:

HIVIAIDS - Research and Palliative Care

\section{Zakir Abdu (D) \\ Aman Dule (D)}

Department of Psychiatry, Faculty of Health and Medical Sciences, Mettu University, Mettu, Ethiopia
Correspondence: Zakir Abdu

Tel +25l 91384537 I

Email zakirabdu45@gmail.com
Background: In comparison to the general population, persons living with HIV show a higher prevalence of poor quality of sleep, with estimates from $24.1-100 \%$ vs in the normal population $10-40 \%$. There are not enough data on the poor quality of sleep among HIV-infected persons in Ethiopia.

Methods: Hospital-based cross-sectional study design was conducted among 336 HIVinfected persons in Mettu Karl Referral Hospital. Pittsburgh sleep quality index (PSQI), social phobia inventory (SPIN), changes in sexual functioning questionnaire short-form (CSFQ-14), Fagerstrom test for nicotine dependence (FTND), severity of dependence scale (SDS), and CAGE questionnaire (cut down, annoyed, guilty, eye opener) was used. Data were analyzed by SPSS 20 version. Bivariate and multivariable regressions were computed, and a significance level was declared at a point $P$-value of $<0.05$.

Results: A total of 336 respondents completed all questionnaires with response rate $98.53 \%$. A total of 192 participants $(57.1 \%)$ had poor sleep quality. Concerning associated factors; positive for social phobia, sexual dysfunction, living alone, poor antiretroviral (ARV) treatment adherence, and drunken alcohol had a positive association with poor sleep quality.

Conclusion: Of the persons living with HIV (PLWH) in Mettu Karl Referral Hospital, $57.1 \%$ experienced poor sleep quality. Social phobia, living arrangement, sexual dysfunction, poor ARV treatment adherence, and use of alcohol showed a significant association with poor quality of sleep. The findings suggest that a longitudinal study will be needed to elucidate the causal relationship of variables, and routine screening of poor sleep quality among PLWH is highly recommended. Furthermore, integrating and launching mental health services at ART clinic is greatly important.

Keywords: poor sleep quality, Mettu Karl hospital, PLWH

\section{Introduction}

Poor quality of sleep can impede normal health functioning. ${ }^{1}$ Good sleep is an index of wellbeing. ${ }^{2}$ Poor sleep quality is commonly reported in medical disorders, ${ }^{3,4}$ especially in human immunodeficiency virus (HIV) positive individuals $^{5-7}$ and it is the most common complaints of persons living with HIV (PLWH). ${ }^{1,3,8}$ In particular, poor sleep quality has been known in PLWH since the early days of the epidemic. ${ }^{1,9}$

Poor sleep quality has damaging effects equivalent to major sleep disturbances. The high rate and direct or indirect healthcare effects of poor quality of sleep now a days accounts for a more serious medical disorder. ${ }^{2}$ Poor sleep quality overwhelms the overall health of individuals. ${ }^{10}$ 
Poor sleep quality is a clinical and public health problem. ${ }^{5}$ It is linked with increased risk of he general quality-of-life, ${ }^{2}$ both in a clinical population ${ }^{11}$ and in the normal population. ${ }^{12}$

In contrast to the normal population, PLWH report a high rate of poor quality sleep, ${ }^{13-16}$ with estimates ranging from $24.1-100 \%{ }^{6,-17-20}$ vs in the normal population $(10-40 \%){ }^{17,19,21}$ In addition, HIV-positive individuals reveal a greater risk of facing poor quality of sleep than the rest of seriously medical ill patients. ${ }^{22}$ Different problems effecting PLWH designate the consequence of manifesting many difficulties related to sleep disturbances. ${ }^{13}$

Patients with human immunodeficiency virus/Acquired immunodeficiency syndrome (HIV/AIDS) are most of the time affected by poor quality of sleep because of multiple factors like HIV-involvement and opportunistic infections of the central nervous system (CNS), most of the time risk of substance use, side-effects of antiretrovirals (ARV), different medical comorbidity, and decrement of the immune system. ${ }^{21,23,24}$ Poor quality of sleep was forecast by disorders like depression, anxiety, substance use disorder, and long duration of living with HIV/AIDS. ${ }^{3,-5,-7,-10,-12,-15,-16,-25-28}$ In contrast, some literature confirms depression and anxiety disorders did not show a significant association with poor quality of sleep. $^{29}$

Among PLWH, poor quality of sleep has been resulting in poor health, poor ARV treatment adherence, deterioration in quality-of-life, immune system, and physical health, diminished growth of cell, affecting neuronal connections and malfunctions. ${ }^{5,30}$ There was a scarcity of data regarding poor quality of sleep among PLWH in Ethiopia. Therefore, the findings of the current study will serve as a baseline for the study of a similar topic and also an input for policy makers, planners, those who are working in higher institutions, and health professionals to use a right method to solve the problem of poor quality of sleep and associated factors in PLWH. That is why we are interested to conduct this research.

\section{Methods}

\section{Study Setting}

This study was carried out in Mettu Karl Referral Hospital (MKRH). MKRH is the only referral hospital found in the Ilu Aba Bor zone. Mettu town is located at 600 kilometers southwest of the capital city of Ethiopia, Addis Ababa. MKRH is giving service for two zones of Oromia regional state (Ilu Aba Bor zone and Buno Bedele zone) and Gembela regional state.

\section{Study Design and Period}

An institutional-based cross-sectional study was conducted from May 1-30, 2020.

\section{Study Population}

All PLWH on follow-up at MKRH during the data collection period.

\section{Sample Size Determination}

The sample size was calculated by using a single population proportion formula at a confidence interval of $95 \%$, a marginal error of $5 \%$, and estimated proportion $50 \%$. The total number of populations who had to follow-up during data collection was 1,600 . Finally, using a correction formula and adding a $10 \%$ non-response rate, the sample size was 341 .

\section{Sampling Technique}

To select 341 HIV/AIDS patients, a systematic sampling technique was used. Sampling interval, $k$, was calculated by $1,600 / 341 \approx 4$.

Therefore, every $4^{\text {th }}$ interval, study participants were selected until the required sample was filled.

\section{Data Collection Procedure and Tools}

Data was collected by face-to-face interview technique. Initially a questionnaire in English language was prepared. This was then translated into local languages, Amharic and Afan Oromo. To check for consistency, the questionnaire was translated back to English by a language professional. The questionnaire has different subsections: Socio-economic and demographic factors, Pittsburgh sleep quality index (PSQI), social phobia inventory (SPIN), changes in sexual functioning questionnaire short-form (CSFQ-14), Fagerstrom test for nicotine dependence (FTND), severity of dependence scale (SDS), and CAGE questionnaire (cut down, annoyed, guilty, eye-opener). Poor quality of sleep was screened by PSQI. Validity and reliability of PSQI was done. ${ }^{31}$ The PSQI scoring of the answers is based on a 0-3 scale. A cut-off point " 5 " and above shows "poor sleep quality". ${ }^{31}$ In PLWH, PSQI is the most widely validated instrument used to assess poor quality of sleep. ${ }^{6}$ SPIN was used to assess social anxiety. A total score of $\geq 19$ indicates a social anxiety disorder. ${ }^{32}$ Validation of SPIN was done in Nigeria. ${ }^{33}$ CSFQ-14 has separate forms of female (CSFQ-F) and male (CSFQ-M) data. CSFQ has 14 items. Except for items \#10 and \#14, higher scores reflect higher sexual functioning (eg, $1=$ never 
to $5=$ every day). For both items \#10 and \#14, higher sexual functioning corresponds to lower frequency (eg, $1=$ every day to $5=$ never). From the global sum of CSFQ-14, the cut-off point for a female is 41 and below, while 47 and below to said individuals have sexual dysfunction. ${ }^{34}$

Tobacco use was assessed using FTND. This is a structured interviewer-administered questionnaire with a global score of $10{ }^{35}$ A cut-off score of 5 and above indicates tobacco dependence, also sensitivity and specificity for FTND was done. ${ }^{36}$

Khat use disorder was screened by SDS. ${ }^{37}$ SDS was validated in Ethiopia. The total score is obtained by the addition of 5-items. ${ }^{38,39}$

In this study, the CAGE questionnaire was used to screen AUD. A cut-off point $\geq 2$ for males and $\geq 1$ for females was used. ${ }^{40-42}$

\section{Operational Definition}

Poor quality of sleep: Individuals had poor quality of sleep if they scored a total score of " 5 " and above of PSQI.

Sexual dysfunction: As this study, individuals have sexual dysfunction when they scored 41 and below for female and 47 and below for male CSFQ elements.

Social anxiety: A global score of $\geq 19$ of SPIN.

\section{Data Analysis}

SPSS version 20 was used to analyse the data. Bivariate and multivariable logistic regressions were used and the significance of association was declared at a $P$-value of 0.05 .

\section{Ethical Considerations}

For this study, ethical clearance was obtained from Mettu University, Faculty of health sciences. And a support letter from the department of psychiatry and permission was obtained from MKRH administrators'. Participation was totally voluntary and confidentiality was ensured.

\section{Results}

\section{Socio-Demographic and Economic Characteristics of Respondents}

From 341, 336 participants completed all items. Among the 336 participants, the majority of participants were males. The participants mean age was $32.61(\mathrm{SD} \pm 8.45)$. The majority of the participants $(270 ; 80.4 \%)$ were from urban areas. Most subjects were male, married, and
Table I Background Characteristics of Study Participants Among Persons Living with HIV, South West Ethiopia, June $2020(\mathrm{~N}=336)$

\begin{tabular}{|c|c|c|c|}
\hline $\begin{array}{l}\text { Study } \\
\text { Variables }\end{array}$ & Response & $\begin{array}{l}\text { Frequency } \\
\text { (N) }\end{array}$ & $\begin{array}{l}\text { Percentage } \\
\text { (\%) }\end{array}$ \\
\hline Gender & $\begin{array}{l}\text { Male } \\
\text { Female }\end{array}$ & $\begin{array}{l}185 \\
151\end{array}$ & $\begin{array}{l}55.1 \\
44.9\end{array}$ \\
\hline $\begin{array}{l}\text { Educational } \\
\text { status }\end{array}$ & $\begin{array}{l}\text { Unable to read and } \\
\text { write } \\
\text { Primary education } \\
\text { Secondary education } \\
\text { College and above }\end{array}$ & $\begin{array}{l}67 \\
130 \\
116 \\
23\end{array}$ & $\begin{array}{l}19.0 \\
38.7 \\
34.5 \\
6.8\end{array}$ \\
\hline Age (mean $\pm S D)$ & & & $32.61 \pm 8.45$ \\
\hline Religion & $\begin{array}{l}\text { Orthodox } \\
\text { Muslim } \\
\text { Protestant } \\
\text { Others* }\end{array}$ & $\begin{array}{l}140 \\
100 \\
81 \\
15\end{array}$ & $\begin{array}{l}41.7 \\
29.8 \\
24.1 \\
4.4\end{array}$ \\
\hline Residence & $\begin{array}{l}\text { Rural } \\
\text { Urban }\end{array}$ & $\begin{array}{l}137 \\
173\end{array}$ & $\begin{array}{l}44.2 \\
55.8\end{array}$ \\
\hline Job & $\begin{array}{l}\text { Have a permanent } \\
\text { job } \\
\text { No permanent job }\end{array}$ & $\begin{array}{l}184 \\
152\end{array}$ & $\begin{array}{l}54.8 \\
45.2\end{array}$ \\
\hline $\begin{array}{l}\text { Living } \\
\text { arrangement }\end{array}$ & $\begin{array}{l}\text { With family } \\
\text { Alone }\end{array}$ & $\begin{array}{l}271 \\
65\end{array}$ & $\begin{array}{l}80.7 \\
19.3\end{array}$ \\
\hline
\end{tabular}

Note: *Catholic, Wakefata.

had a permanent job (Table 1). Average duration of diagnosis with HIV is 7.8 years (Table 2).

\section{Prevalence of Poor Quality of Sleep}

From the participants who completed the study, 144 (42.9\%) of them reported good quality of sleep and 192 $(57.1 \%)$ of them reported poor quality of sleep.

\section{Factors Associated with Poor Quality of Sleep}

Variables like residence, nicotine dependence, and lack of permanent job was not associated with poor quality of sleep in the bivariate logistic regression analysis. However, gender, khat use disorder, educational status, duration of diagnosis with HIV, and duration of starting ART were associated with poor quality of sleep in the bivariate analysis, but did not show a significant association in the final model.

Multivariable logistic regression analysis revealed that social phobia, living arrangement, sexual dysfunction, poor ARV treatment adherence, and use of alcohol showed a significant association with poor quality of sleep. 
Table 2 HIV-Related Clinical Characteristics of Study Participants Among Persons Living with HIV, South West Ethiopia, June $2020(\mathrm{~N}=336)$

\begin{tabular}{|c|c|c|c|}
\hline Study Variables & $\begin{array}{l}\text { Categoryl } \\
\text { Response }\end{array}$ & $\begin{array}{l}\text { Frequency } \\
\text { (N) }\end{array}$ & $\begin{array}{l}\text { Percentage } \\
\text { (\%) }\end{array}$ \\
\hline $\begin{array}{l}\text { Duration of } \\
\text { diagnosis with HIV }\end{array}$ & $\begin{array}{l}\leq 7.8 \text { years } \\
>7.8 \text { years }\end{array}$ & $\begin{array}{l}151 \\
185\end{array}$ & $\begin{array}{l}44.9 \\
55.1\end{array}$ \\
\hline $\begin{array}{l}\text { Duration of started } \\
\text { ART }\end{array}$ & $\begin{array}{l}\leq 6.8 \text { years } \\
>6.8 \text { years }\end{array}$ & $\begin{array}{l}174 \\
162\end{array}$ & $\begin{array}{l}51.8 \\
48.2\end{array}$ \\
\hline $\begin{array}{l}\text { Medication } \\
\text { adherence* }\end{array}$ & $\begin{array}{l}\text { Yes } \\
\text { No }\end{array}$ & $\begin{array}{l}195 \\
141\end{array}$ & $\begin{array}{l}58 \\
42\end{array}$ \\
\hline $\begin{array}{l}\text { Way became } \\
\text { infected by HIV }\end{array}$ & $\begin{array}{l}\text { Sex with } \\
\text { female } \\
\text { Sex with } \\
\text { male } \\
\text { Not known } \\
\text { Others** }\end{array}$ & $\begin{array}{l}155 \\
138 \\
21 \\
22\end{array}$ & $\begin{array}{l}46.1 \\
41.1 \\
6.3 \\
6.5\end{array}$ \\
\hline $\begin{array}{l}\text { Nicotine } \\
\text { dependence }\end{array}$ & $\begin{array}{l}\text { Yes } \\
\text { No }\end{array}$ & $\begin{array}{l}30 \\
306\end{array}$ & $\begin{array}{l}8.9 \\
91.1\end{array}$ \\
\hline Khat use disorder & $\begin{array}{l}\text { Yes } \\
\text { No }\end{array}$ & $\begin{array}{l}112 \\
224\end{array}$ & $\begin{array}{l}33.3 \\
66.7\end{array}$ \\
\hline $\begin{array}{l}\text { Alcohol use } \\
\text { disorder }\end{array}$ & $\begin{array}{l}\text { Yes } \\
\text { No }\end{array}$ & $\begin{array}{l}89 \\
247\end{array}$ & $\begin{array}{l}26.5 \\
73.5\end{array}$ \\
\hline Sexual dysfunction & $\begin{array}{l}\text { Yes } \\
\text { No }\end{array}$ & $\begin{array}{l}242 \\
94\end{array}$ & $\begin{array}{l}72 \\
28\end{array}$ \\
\hline Social phobia & $\begin{array}{l}\text { Yes } \\
\text { No }\end{array}$ & $\begin{array}{l}109 \\
227\end{array}$ & $\begin{array}{l}32.4 \\
67.6\end{array}$ \\
\hline
\end{tabular}

Notes: *In this study medication adherence was identified as taking medication in the past I month without missing any dose; **From family, by using the infected sharp material.

Accordingly, the odds of having poor quality of sleep among participants who had alcohol use disorder was 2.94-times higher $(\mathrm{AOR}=2.94,95 \% \mathrm{CI}=1.49-5.81)$ compared with those who did not use alcohol. The odds of having poor quality of sleep among participants who were living alone was 2.36times higher $(\mathrm{AOR}=2.36,95 \% \mathrm{CI}=1.14-4.88)$ compared with those who were living with their family. The odds of having poor quality of sleep among participants with social phobia were 1.79-times higher ( $\mathrm{AOR}=1.79,95 \% \mathrm{CI}=1.05-3.05)$ than the participants who have no social phobia. The odds of having poor quality of sleep was 5.77-times more likely ( $\mathrm{AOR}=5.77$, 95\% CI $=3.16-10.52)$ in participants with sexual dysfunction as compared with participants who have no sexual dysfunction. Participants with poor ARV treatment adherence were 2.58 -times $(\mathrm{AOR}=2.58,95 \% \mathrm{CI}=1.42-4.68)$ more likely to develop poorer quality of sleep than participants with medication adherence (Table 3). The components of the PSQI scored by individuals were compared in participants with poor and good quality of sleep (Table 4).

\section{Discussion}

To our knowledge, there were no published data on the magnitude of poor quality of sleep among PLWH in Ethiopia. So, the current study was a first study at the national level, and $57.1 \%$ experienced poor sleep quality. This result is in line with the results of previous studies in Nigeria, ${ }^{28}$ South Africa, ${ }^{43}$ and the US ${ }^{44}$ However, when comparing the current finding with the results in Nigeria, ${ }^{23}$ in Brazil, ${ }^{45}$ in Iran,${ }^{10}$ in China, ${ }^{26}$ in France, ${ }^{46}$ at the University of California, ${ }^{5}$ and in the US, ${ }^{25}$ the results seem higher. On the other hand, the finding of poor quality of sleep in the current study was lower than the previous study conducted in the US. ${ }^{15,47}$

The reported variations between different studies may be due to different socioeconomic status and cultural background among the current and the previous studies. The other reason could be differences in geographical area, characteristics of participants, variation in and status of hospitals, and the service delivery. A possible reason of why the current result was lower than the previous study could be the previous study was conducted many years ago and on a small sample size ${ }^{15,47}$ and also a difference in study design and sampling technique among both studies. ${ }^{47}$

The odds of reporting poor quality of sleep among participants with alcohol use disorder was higher than the respondents without alcohol use disorder. The possible reasons might be that this is an effect of the substances on the brain results in sustained use of a CNS depressant, such as alcohol, can cause somnolence. This finding, consistent with previous findings, found that substance use was a significantly predictor of poor quality of sleep among PLWH. ${ }^{3}$ Individuals who use alcohol as a sleep inducer are more exhausted and manifest more daytime sleepiness than their counterparts ${ }^{48}$ and also there is a finding which concludes that there is a negative correlation between sleep times and alcohol consumption. ${ }^{49}$ Participants who drunkalcohol were more likely to suffer from poor sleep than those who did not drink. ${ }^{50}$

The current results confirmed that respondents living alone reported more poor quality of sleep as compared with respondents living with their family. A possible reason could be that respondents living alone could not get sufficient support and help from family or relatives as they 
Table 3 Factors Associated with Poor Quality of Sleep by Bivariate and Multivariate Logistic Regression Among Persons with HIV, South West Ethiopia, June $2020(\mathrm{~N}=336)$

\begin{tabular}{|c|c|c|c|c|c|}
\hline \multirow[t]{3}{*}{ Study Variables } & \multicolumn{2}{|c|}{ Sleep Quality } & \multirow[t]{3}{*}{ COR $(95 \% \mathrm{Cl})$} & \multirow[t]{3}{*}{ AOR $(95 \% \mathrm{CI})$} & \multirow[t]{3}{*}{$P$-value } \\
\hline & Poor & Good & & & \\
\hline & 192 (57.| \%) & I 44 (42.9\%) & & & \\
\hline \multicolumn{6}{|l|}{ Living arrangement } \\
\hline Alone & $47(72.3)$ & $18(27.7)$ & $2.26(1.25-4.10)^{*}$ & $2.36(1.14-4.88)$ & 0.02 \\
\hline With family & $145(53.5)$ & $126(46.5)$ & Ref & Ref & \\
\hline \multicolumn{6}{|l|}{ Social phobia } \\
\hline Yes & $72(66.1)$ & 37 (33.9) & $1.73(1.08-2.78) * *$ & $1.79(1.05-3.05)$ & 0.03 \\
\hline No & $120(52.9)$ & $107(47.1)$ & Ref & Ref & \\
\hline \multicolumn{6}{|l|}{ Sexual dysfunction } \\
\hline Yes & 159 (65.7) & $83(34.3)$ & $3.54(2.14-5.83) * * *$ & $5.77(3.16-10.52)$ & $<0.001$ \\
\hline No & $33(35.1)$ & $61(64.9)$ & Ref & Ref & \\
\hline \multicolumn{6}{|l|}{ Medication adherence } \\
\hline Yes & $93(47.7)$ & $102(52.3)$ & Ref & Ref & 0.002 \\
\hline No & $99(70.2)$ & $42(29.8)$ & $2.58(1.63-4.08) * * *$ & $2.58(1.42-4.68)$ & \\
\hline \multicolumn{6}{|l|}{ Alcohol use disorder } \\
\hline Yes & $69(77.5)$ & $20(22.5)$ & $3.47(1.99-6.06) * * *$ & $2.94(\mathrm{I} .49-5.8 \mathrm{I})$ & 0.002 \\
\hline No & $123(49.8)$ & $124(50.2)$ & Ref & Ref & \\
\hline
\end{tabular}

Notes: $* P=0.007, * * P=0.023, * * * P<0.001$ (in bivariate model).

Table 4 Comparison of the Individual Component Score of the PSQI Among Patients with Poor and Good Quality of Sleep, South West Ethiopia, June $2020(\mathrm{~N}=336)$

\begin{tabular}{|l|l|l|l|}
\hline PSQI Components & $\begin{array}{l}\text { Poor Sleep } \\
\text { Quality } \\
(\mathbf{n}=\mathbf{1 9 2}) \\
\text { Mean and SD }\end{array}$ & $\begin{array}{l}\text { Good Sleep } \\
\text { Quality } \\
(\mathbf{n}=\mathbf{1 4 4}) \\
\text { Mean and SD }\end{array}$ & P-value \\
\hline C-I Quality of sleep & $1.10 \pm 0.51$ & $0.10 \pm 0.29$ & $<0.001$ \\
C-2 Sleep latency & $1.08 \pm 0.68$ & $0.65 \pm 0.70$ & $<0.001$ \\
C-3 Sleep duration & $0.19 \pm 0.47$ & $0.05 \pm 0.21$ & 0.001 \\
C-4 Sleep efficiency & $0.75 \pm 0.94$ & $0.01 \pm 0.11$ & $<0.001$ \\
C-5 Sleep disturbances & $1.28 \pm 0.49$ & $0.33 \pm 0.47$ & $<0.001$ \\
C-6 Sleep medication & $0.51 \pm 0.85$ & $0 \pm 0$ & $<0.001$ \\
C-7 Daytime sleepiness & $0.99 \pm 0.40$ & $0.15 \pm 0.35$ & $<0.001$ \\
\hline
\end{tabular}

wanted. This result is in line with previous results reported from France. ${ }^{7}$

The present study also found that three new significant variables: social phobia, sexual dysfunction, and poor ARV treatment adherence, were associated with poor quality of sleep.

The results of the current study showthat individuals with social phobia reported more poor quality of sleep as compared with their counterparts. The reason could be that participants with social anxiety might be thinking about their daily activities because they became fearful of social situations in which the individual is defenseless to new face persons. Because of this, the sleep of participants' with social phobia might be disturbed. This result is in line with previous results that psychological related factors associated with poor quality of sleep among PLWH. ${ }^{7,26}$

Our study revealed that of the respondents, those with sexual dysfunction reported worse quality of sleep when compared with their counterparts. The probable reason could be individuals with sexual dysfunction probably might not be in a good relationship with their partner. Interference in a relationship might lead to disagreement and an unstable family. This can be ruinous to PLWH, thereby causing worsening in their psychological and social wellbeing and lead to them to become more predisposed to poor quality of sleep. There is also data which support our findings that patientd with erectile dysfunction might report poorer quality of sleep. ${ }^{51}$

Finally, in our study, there is a strong association between poor quality of sleep and poor ARV treatment adherence. Even though, to our knowledge, there are no consistent data which support the current findings, the probable reason could be when HIV positive patients are not adhering to their medication; it is known to result in accretion of viruses. Accretion of viruses might result in 
lessening health-related quality-of-life and diminished cognition, which might result in poor sleep quality among PLWH.

\section{Strength of the Study}

- To our knowledge, there were no published data on the magnitude of poor quality of sleep among PLWH in Ethiopia, and this study was a first.

- In this study, different standardized and validated tools like PSQI, CAGE, CSFQ-14, FTND, and SDS were used.

- The other strength of this study is that new variables like social phobia, sexual dysfunction, and poor ARV treatment adherence were assessed as they had a significant association with poor quality of sleep among PLWH. Almost 50\% of the participants were female.

\section{Limitations of the Study}

- Study subjects for this study were collected from one hospital, which is MKRH and serving a large population in South west Oromia and Gembela regional state.

- Due to its study design being cross-sectional, the study could not identify the temporal relationship of variables.

\section{Conclusion}

Of the PLWH in Mettu Karl Referral Hospital, 57.1\% experienced poor sleep quality. Multivariable logistic regression analysis revealed that social phobia, living arrangement, sexual dysfunction, poor ARV treatment adherence, and use of alcohol showed significant associations with poor quality of sleep. The findings suggest that a longitudinal study will be needed to elucidate the causal relationship of variables and routine screening of poor sleep quality among PLWH is highly recommended. Furthermore, integrating and launching mental health services at the ART clinic is greatly important.

\section{Abbreviations}

ARV, antiretroviral; CAGE, cut down, annoyed, guilty, eye opener; CNS, central nervous system; CSFQ-14, changes in sexual functioning questionnaire short-form; CI, confidence interval; FTND, Fagerstrom test for nicotine dependence; HIV, human immunodeficiency virus; PLWH, people living with HIV; PSQI, Pittsburgh sleep quality index; SDS, severity of dependence scale; SPIN, social phobia inventory.

\section{Data Sharing Statement}

The data sets used and analyzed during the current study are available from the corresponding author on reasonable request.

\section{Ethical Consideration}

An ethics letter was given from the ethical review committee of the Faculty of health, Mettu University. The study was performed in accordance with the Declaration of Helsinki. Written informed consent was obtained from each participant for their participation. Participants included in the study were age 18 year and above. Selected participants were told about the nature, purpose, benefits, and adverse effects of the study, and invited to participate. Participation was totally voluntary and confidentiality was ensured.

\section{Consent for Publication}

Not applicable.

\section{Acknowledgments}

We would like to thank Mettu University and Mettu Karl Referral Hospital for giving us the opportunity. We are also grateful to our study participants, data collectors/ supervisors, and head of departments for their great contribution and support.

\section{Author Contributions}

All authors made substantial contributions to the conception and design, acquisition of data, or analysis and interpretation of data; took part in drafting the article or revising it critically for important intellectual content; agreed to submit to the current journal; gave final approval of the version to be published; and agree to be accountable for all aspects of the work.

\section{Funding}

None institution fund this thesis and done by authors fund.

\section{Disclosure}

The authors declare that they have no competing interests.

\section{References}

1. Wiegand M, Miiiler AA, Schreiber W, et al. Nocturnal sleep EEG in patients with HIV infection. Eur Arch Psychiatry Clin Neurosci. 1991;240:153-158.

2. Garbarino S, Lanteri P, Durando P, Magnavita N, Sannita WG. Comorbidity, mortality, quality of life and the healthcare/welfare/social costs of disordered sleep: a rapid review. Int J Environ Res Public Heal. 2016;13:831. doi:10.3390/ijerph13080831 
3. Estrada ER, Candela Iglesias Chiesa M, Ana Fresán Orellana GR-T. Factors associated with poor sleep quality among HIV-positive individuals in Mexico City. Salud Ment. 2018;41(3):123-129. doi:10.17711/SM.0185-3325.2018.016

4. Berry RB, Harding SM. Sleep and medical disorders. Med Clin N Am. 2004;88:679-703.

5. Saberi P, Pharm D, Torsten B, Neilands and MOJ. Quality of sleep: associations with antiretroviral nonadherence. AIDS Patient Care STDS. 2011;25(9). doi:10.1089/apc.2010.0375

6. Wu J, Wu H, Lu C, Guo L, Li P. Self-reported sleep disturbances in HIV-infected people: a meta-analysis of prevalence and moderators. Elsevier Sleep Med. 2015;16(8):901-907. doi:10.1016/j.sleep.2015. 03.027

7. Allavena C, Guimard T, Billaud E, Reliquet SDT V. Prevalence and risk factors of sleep disturbance in a large HIV-infected adult population. AIDS Behav. 2015. doi:10.1007/s10461-015-1160-5

8. Vosvick M, Gore-felton C, Ashton E, et al. Sleep disturbances among HIV-positive adults The role of pain, stress, and social support. J Psychosom Res. 2004;57:459-463. doi:10.1016/j.jpsychores.2004. 03.003

9. Infection IHI V, Norman SE, Chediak AD, Freeman C, et al. Sleep disturbances in men with asymptomatic human. Clin Res. 1992;15 (2):150-155.

10. Dabaghzadeh F. Sleep quality and its correlates in HIV positive patients who are candidates for initiation of antiretroviral therapy original article sleep quality and its correlates in HIV positive patients who are candidates for initiation of antiretroviral therapy. Iran J Psychiatry. 2013;8(4):160-164.

11. Koren D, Dumin M, Gozal D. Role of sleep quality in the metabolic syndrome. Diabetes Metab Syndr Obes Targets Ther. 2016;9:281-310. doi:10.2147/DMSO.S95120

12. Hayashino Y, Yamazaki S, Takegami M, Nakayama T, Sokejima S. Association between number of comorbid conditions, depression, and sleep quality using the Pittsburgh Sleep Quality Index: results from a population-based survey. Sleep Med. 2010;11(4):366-371. doi:10.1016/j.sleep.2009.05.021

13. McDaniel JR, Walter C, Buboltz J, Chauvin IV, Ondie LM, Eddlemon BS. Sleep quality and habits of adults with the human immunodeficiency virus. Int J Humanit Soc Sci. 2011;1AD:7.

14. Mahmood Z, Hammond A, Nunez RA, et al. HHS Public Access. J Int Neuropsychol Soc. 2018;24(10):1038-1046. doi:10.1017/ S1355617718000607

15. High prevalence of insomnia in out patient population with HIV infection. J Acquir Immune Deficiency Syndr Hum Retrovirol. 1998;19(3):260-265.

16. Wibbeler T, Reichelt D, Husstedt I, Evers S. Sleepiness and sleep quality in patients with HIV infection. J Psychosom Res. 2012;72 (6):439-442. doi:10.1016/j.jpsychores.2012.03.003

17. Low Y, Goforth H, Preud'homme X, Jack Edinger AK. Insomnia in HIV-infected Patients: pathophysiologic Implications. AIDS Rev. 2014;16:3-13.

18. Taibi DM, PhD R. Sleep disturbances in persons living with HIV. $J$ Assoc Nurses AIDS Care. 2014;24(S72-S85):1-19. doi:10.1016/j. jana.2012.10.006

19. Ning C, Lin H, Chen X, et al. Cross-sectional comparison of various sleep disturbances among sex- and age-matched HIV-infected versus HIV-uninfected individuals in China. Sleep Med. 2019. doi:10.1016/j. sleep.2019.06.020

20. Lee KA, Caryl Gay CJ, Portillo TC, Harvey Davis CR, Pullinger BEA. Types of sleep problems in adults living with HIV/ AIDS. J Clin Sleep Med. 2012;8(1):67-75. doi:10.5664/jcsm.1666

21. Mrcpsych SR, Justin Dwyer DM. Insomnia in HIV infection: a systematic review of prevalence, correlates, and management. Psychosom Med. 2005;67:260-269. doi:10.1097/01.psy.0000151771. 46127.df
22. Chen Y-C, Lin C-Y, Strong C, Chung-Yi Li J-SW, Wen-Chien Ko N-YK. Sleep disturbances at the time of a new diagnosis: a comparative study of human immunodeficiency virus patients, cancer patients, and general population controls. Sleep Med. 2017;36:38-43. doi:10.1016/j.sleep.2017.04.005

23. Bisong EM, Williams UE, Okpa HO, et al. Predictors of Sleep Disorders among HIV out-patients in a tertiary hospital. Recent $A d v$ Biol Med. 2017;3(103):103-109.

24. Irwin MR, Olmstead R, Carroll JE. Archival report sleep disturbance, sleep duration, and in flammation: a systematic review and meta-analysis of cohort studies and experimental sleep deprivation. Biol Psychiatry. 2015;1-13.

25. Crum-Cianflone NF, Roediger MP, Moore DJ, et al. Prevalence and factors associated with sleep prevalence and factors associated with sleep disturbances among early-treated HIV-infected persons. Clin Infect Dis. 2012;54(10):85-94. doi:10.1093/cid/cis192

26. Huang X, Li H, Meyers K, Xia W, Meng Z, Li C. Burden of sleep disturbances and associated risk factors: a cross- sectional survey among HIV- infected persons on antiretroviral therapy across China. 2017;(October 2016):1-8.

27. Mahoney JJ III, Jackson BJ, Christopher D, Ho VA, Tabish Iqbal TFN. The relationship between sleep and drug use characteristics in participants with cocaine or methamphetamine use disorders. Psychiatry Res. 2014.

28. Oshinaike O, Akinbami A, Ojelabi O, Dada A, Dosunmu A, Olabode SJ. Quality of sleep in an HIV population on antiretroviral therapy at an urban tertiary Centre in Lagos, Nigeria. Hindawi Publ Corp. 2014;2014. doi:10.1155/2014/298703

29. Buchanan DT, McCurry SM, Eilers K, Shauna Applin E, Voss TW. Brief behavioral treatment for insomnia in persons living with HIV. Behav Sleep Med. 2016.

30. Qaseem A, Kansagara D, Forciea MA, Cooke M. Management of chronic insomnia disorder in adults: a clinical practice guideline from the american college of physicians. Ann Intern Med. 2016;165:125-13333.

31. Buysse DJ, Reynolds III, Monk CF, Berman TH, Kupfer DJ. The Pittsburgh Sleep Quality Index: A new instrument for psychiatric practice and research. J Psychiatr Res. 1989;28(2):193-213.

32. Davidson J. Social Phobia Inventory (SPIN). 1995. Available from: www.brusheducation.ca. Accessed October 6, 2020.

33. Chukwujekwu DCOE. Validation of the Social Phobia Inventory (SPIN) in Nigeria. J Psychiatry Psychiatr Disord. 2018;2(2):49-54. doi:10.26502/jppd.2572-519X0040

34. Adrienne Keller ELMAAHC. Reliability and construct validity of the changes in sexual functioning questionnaire Short-Form (CSFQ-14). J Sex Marital Ther. 2006;32:43-52. doi:10.1080/0092623050023 2909

35. Kozlowski LT, Frecker RC. The Fagerstrom test for nicotine dependence: a revision of the Fagerstrom Tolerance Questionnaire. $\mathrm{Br}$ J Addict. 1991;86:1119-1127.

36. Klinsophon T, Prawit Janwantanakul PT. Reliability of the Thai Version of the Fagerstrom Test for Nicotine Dependence (FTND). J Med Assoc Thai. 2017;100(101):1130-1134.

37. Benjamin James Sadock VAS. Kaplan \& Sadock's Synopsis of Psychiatry Behavioral Sciences/Clinical Psychiatry. 10th ed. 2007.

38. Martin G, Copeland J, Gates P, Gilmore S. The Severity of Dependence Scale (SDS) in an adolescent population of cannabis users: reliability, validity and diagnostic cut-off. Drug Alcohol Depend. 2006;83:90-93.

39. Dilshad Manzar M, Alamri M, Mohammed S, et al. Psychometric properties of the severity of the dependence scale for Khat (SDS-Khat) in polysubstance users. BMC Psychiatry. 2018;18(343). doi:10.1186/s12888-018-1917-2

40. CAGE. Substance Abuse Screening Tool. Johns Hopkins Health care; 1984. 
41. Canadian Guideline for Safe and Effective Use of Opioids for CNCP Part $B$. Alcohol And Drug Abuse Institute University of Washington.

42. Williams N. The CAGE Questionnaire. Vol. 64. Occupational Medicine;2014:473-474. doi:10.1093/occmed/kqu058

43. Redman KN, Karstaedt AS, Brain SK. Behavior, and Immunity Increased CD4 counts, pain and depression are correlates of lower sleep quality in treated HIV positive patients with low baseline CD4 counts. Brain Behav Immun. 2018;69:548-555. doi:10.1016/j.bbi.2018.02.002

44. Gamaldo CE, Spira AP, Hock RS, et al. NIH Public Access.. AIDS Behav. 2013;17(8):2808-2815. doi:10.1007/s10461-012-0401-0

45. Tiemi L, Ferreira K, Ceolim MF. Sleep quality in HIV-positive outpatients. Rev Esc Enferm USP. 2012;46(4):890-896.

46. Allavena C, Guimard T, Billaud E, et al. Prevalence and risk factors of sleep disturbances in a large HIV infected adult population. J Int AIDS Soc. 2014;17. doi:10.7448/IAS.17.4.19576
47. Gutierrez J, Tedaldi EM, Armon C, Patel V, Rachel Hart KB. Sleep disturbances in HIV-infected patients associated with depression and high risk of obstructive sleep apnea. SAGE Open Med. 2019;7:1-11. doi: $10.1177 / 2050312119842268$

48. Michael D. Stein PDF. Disturbed sleep and its relationship to alcohol use. Subst Abus. 2005;26(1):1-13. doi:10.1300/J465v26n01_01

49. Timothy Roehrs TR. Sleep, sleepiness, and alcohol use. 2001;25 (1):101-109.

50. Park S-Y, Mi-Kyeong O, Lee B-S, et al. The effects of alcohol on quality of sleep. Korean J Fam Heal. 2015;36:294-299. doi:10.4082/ kjfm.2015.36.6.294

51. Cho JW, Duffy JF. Sleep, sleep disorders, and sexual dysfunction. World J Men's Health. 2018.

\section{Publish your work in this journal}

HIV/AIDS - Research and Palliative Care is an international, peerreviewed open-access journal focusing on advances in research in HIV, its clinical progression and management options including antiviral treatment, palliative care and public healthcare policies to control viral spread. The manuscript management system is completely online and includes a very quick and fair peer-review system, which is all easy to use. Visit http://www.dovepress.com/testimonials.php to read real quotes from published authors. 